\title{
INFORMAL AND FORMAL STEPS IN CONDUCTING DISCUSSIONS AND DEBATES AS WAYS OF TEACHING PHILOSOPHY
}

\author{
UDC $371.3: \because 1$
}

\section{Ivan Nikolić}

University of Niš, Faculty of Philosophy, Department of Philosophy, Niš, Serbia

\begin{abstract}
The intention of the author of this text is to determine a more precise structure of conducting discussions and debates as the best ways for teaching philosophical material. The first part of the text will fully be devoted to trying to set a more precise connection between discussions and debates in as much detail as possible, so that the platform, for which informal and formal steps are being developed for their conduct, would be clearer. Thereby, it will be shown how initiating and conducting discussions is mostly based on informal steps and conducting debates on formal ones. Digressing shortly, the author will try to explain the term dissociation as deeply founded in any approach to philosophical problematics, regardless of its conception as a dialogue or a monologue. For that purpose, a classroom example will be provided. In the final part of the text from the given perspective, the author will single out from a variety of steps recommended for successfully conducted classes the ones which fit such a concept of selecting and conducting discussions and debates the best.
\end{abstract}

Key words: discussion, debate, dissociation, informal steps, formal steps.

\section{INTRODUCTION}

Promoting discussions and debates as the most adequate methods for teaching philosophy requires a certain structure. At first, we are introduced to such a structure through patterns for class conduct set by the bodies responsible for such structuring ${ }^{1}$. However, the structure containing the beginning, the middle, and the end of a lesson, and the methods which should be developed by such a structure, considering philosophy, cannot be of any use in general. To defend such a widely set structure, we will notice that it is more or less conceptualized for subjects with origins in the humanities; therefore, the necessarily applied methods must be selected based on the specificity of the material.

Received November 29, 2019 / January 13, 2020

Corresponding author: Ivan Nikolić

University of Niš, Faculty of Philosophy, Ćirila i Metodija 2, 18000 Niš, Serbia

E-mail: ivan.nikolic@ filfak.ni.ac.rs

${ }^{1}$ Structuring promoted by the Faculty of Philosophy in Niš. See: (Јањић, et al. 2014, 69-72) 
However, directing attention to the dialogue method, the problem method, the text method etc. does not abolish the need to precisely set the structure which we will, in this case, relate to discussions and debates in teaching philosophy. That structure, actually, is also considered with setting a discipline as the necessary condition for conducting discussions and debates, but, we will, for the time being, leave aside the question of setting the discipline and focus only on the steps for structuring philosophical content, under the assumption of fulfilling the condition regarding the discipline.

However, before we determine more comprehensive concepts which, as we think, give the best structure for conducting discussions and debates, it is necessary to precisely determine the differentia specifica which separates debates from discussions. Only this platform allows a detailed explanation of formal and informal steps in their conducting. Namely, regardless of which of the origins in teaching philosophy is considered stronger, the one which promotes skills or the one that sets attitude in the center of development, it is certain that both, at least unintentionally, are aware of the development of the characteristic opposite to the one considered dominant. Therefore, one universal concept has to equally consider the steps related to the development of disposition (informal steps) and the development of logical and methodological skills (formal steps) necessary for the proper conduct of argumentation.

\section{DisCUSSIONS AND DEBATES, KEY DETERMINATIONS}

Starting our investigation on the application of discussions and debates as methods of teaching philosophy we came across a rich bibliography, firstly the contemporary one, that focuses on these two techniques, and it had not previously bothered with the difference between the two. Therefore, our primary task was to try to establish the difference and relationship between these two forms of studying Philosophy. In the beginning it really seems like these two techniques are taken as synonyms and the terms such as 'dispute', 'dissension' etc. appear with similar or even the same meaning. Furthermore, it is possible to anticipate a difference, but it is not sufficiently and precisely enough expressed. Thus, in noun phrases we find the union of both words into one, such as 'Debate Discussion' (Classroom Discussions n.d.) where 'Debate' suggests not only the simple discussion but the existence of a controversial theme and two sides of pro et contra discussants. Also, noun phrases such as 'Developmental Discussion', 'Panel Discussion' and 'Discussion Clusters' (Classroom Discussions n.d.) refer to the fact that during communication there appears a whole hierarchical technique that guides communication. As we will try to present, this hierarchy is determined with argumentative power that is present during the conversation.

From the beginning, the reason for our interest in this differentiation lies in the intuition, during our engagement as philosophy teachers, with which we anticipated that debates had grater argumentative power. That greater power can be anticipated with some theoreticians such as Van Eemeren and others, i.e. in their assertion in which they notice the difference between: "formally regulated juridical and parliamentary debates" and "less formal discussions..." (Van Eemeren, et al. 2014, 1). In addition, during our education, as part of the Methods in Teaching Philosophy course, we could learn more about the importance of these techniques, first of all, the discussion, but only briefly and again without a precise distinction between these two techniques. ${ }^{2}$

${ }^{2}$ See: (Marinkovic 1983, 48-50) 
One of the reasons to this, insufficiently precisely stated distinction, might be explained through various understandings of the word 'argumentation'. Namely, as Van Eemeren and his associates notice: “... there are striking differences between, on the one hand, its lexical meaning in English and, on the other hand, the lexical meaning of its - very common counterparts in other European languages." (Van Eemeren, et al. 2014, 3). The first difference lies in the fact that, as contrary to the English language, other languages do not recognize, at least not on the level of the inscription, the difference between the static and dynamic part of the meaning of this word. It will tell us that 'argumentation' in other languages equally means the process 'of argumentation' and the product 'of argumentation', while in the English language that difference is clearly expressed. On the other hand, languages other than English, recognize one, for us very important difference that will lead us to the intuition that discussions and debates should be observed as separate processes. It is certain that in other languages, the argumentations: "have nothing to do with quarreling, skirmishing, squabbling, bickering, wrangling, haggling, or any other negatively charged verbal activity" and that they are focused on: "reasonableness of the audience" (Van Eemeren, et al. 2014, 4). Therefore, the difference between these two understandings of the word argumentation, suggests that languages other than English, a story that is in advance burdened with prejudices, will not be taken into consideration as argumentation, while in English such a story will be regarded as argumentation too.

However, having in mind the previously listed comparisons, here we need to point out another necessary formal aspect of argumentation which Van Eemeren and his associates make. The final difference that we analyzed points to the fact that argumentation, from the viewpoint of non-English languages, needs to be accepted as formal communication. Still, even then we need to take into consideration the double meaning of the term 'form' through which it occurs. Namely, Van Eemeren and his associates notice that even nonEnglish languages, although they employ the appropriate form, experience a certain deficiency when it comes to understanding the full meaning of argumentation. As they notice: "non-English counterparts refer only to the constellation of propositions put forward in defense of a standpoint without including the standpoint itself as well" (Van Eemeren, et al. 2014, 4). Based on that, we can say that 'reasonableness' in non-English languages is seen as merely a logical validity of the process of argumentation. However, the logical validity of an argument is not sufficient for avoiding prejudices. Avoiding prejudices can be achieved in the full sense only by respecting the logical and the methodological form. Of course, wider elaboration of this side of argumentation would lead us towards a different point than the one we tried to make in our primary statement. The only thing we can say is that, based on previous statements, we can see that argumentation as a means of defending one's own, as well as a means of refuting the positions of other people, demands a clearly defined form. In fact, the strength of an argument is determined by respecting the aforementioned forms.

In the wake of previous differences and moving from a similar position, the position of lexical meaning, we will try to define the difference between discussions and debates. Developing this intuition, we started from the definitions offered by some of the contemporary dictionaries of the English language. Therefore, in the Macmillan dictionary we find the following definition of a term discussion: "a conversation about something, usually something important", (Macmillan Dictionary n.d.). In the Longman dictionary the

\footnotetext{
${ }^{3}$ All the underlined parts in this paragraph have been added by the author of the text.
} 
noun is derived from the verb 'discuss' which is defined as: "to talk about something with another person or a group in order to exchange ideas or decide something..." (Longman Dictionary of Contemporary English n.d.). On the other hand, the term 'debate' is defined as in the first example: "a discussion in which people or groups state different opinions about a subject" (Macmillan Dictionary n.d.), and in the second one as: "discussion of a particular subject that often continues for a long time and in which people express different opinions" (Longman Dictionary of Contemporary English n.d.) and in the end with another definition, probably the most important one, which, among other things, claims that a debate is: "a formal discussion of a particular problem..." (Longman Dictionary of Contemporary English n.d.).

Therefore, as we have already mentioned, there is a certain hierarchy in the approach to a theme that should be elaborated with the pupils. Previously underlined words enable us to move through the hierarchy in an easier way. First of all, a theme should be determined as important. As we see this, it is actually a question of a pedagogic eros or as Batth directs us to the possibilities of a professor: "...put great deal of themselves into their classes and expected a similar level of commitment from their students." (Bhatt 1995, 5-6). Afterwards, it is necessary to create the atmosphere where unhindered exchange of opinions is possible. In the third place, it is good to group various opinions. Actually, as Wallwork notices, the core of the discussion lies exactly in the fact that something in the process of communication is pointed out, divided into opposite sides: "The word 'discuss' originally meant to 'cut' with a similar origin as 'dissect'. This meaning along with its current use of 'examining the pros end cons' gives a good idea of what a discussion is all about..." (Wallwork 1997, 7). All these attempts could be more or less put under the domain of conducting a discussion. We will elaborate them as informal steps of philosophizing, i.e. as steps that initiate a debate. However, the exchange of opinions is not the same as the battle of arguments pro et contra to the solution of a problem. Defining a debate as a 'formal discussion', appears to put in the forefront the power of argumentative conduct of communication. What can be drawn as a pattern to use discussions and debates in philosophy teaching is that we suggest discussion as an introduction, as an approach to a philosophy topic, and a debate as a full and quality development of a given topic. In such a way, the objective of a discussion is to reveal the understanding of those involved in the discussion and to present them to the dynamics of a debate. On the other hand, as it has already been noticed, it is necessary for a debate that the understanding rely on certain criteria that are structured according to certain principles that can be judged pro et contra, so, it is necessary to teach students the affirmative techniques of argumentation through debates. This will be elaborated in the paper through formal steps of philosophizing. If we turn to the definition provided by UNESCO in which philosophy practitioners are recognized, primarily as 'Discussion leaders', furthermore, as a 'philosophy content provider' and finally as a 'referee of philosophical form' (UNESCO 2007, 170), it appears that philosophy teaching is possible to overview in this key. Thus, the above frame from the viewpoint of someone who teaches philosophy counts on the determination of the real contents, quality conduct of a discussion and just trial in the debate.

The fact that we, now, would like to point out is that, very often, especially in the literature on contemporary methods of teaching, it is overlooked that discussions and debates in teaching philosophy are not a novelty from the end of the XX and the beginning of the XXI century. In this period, they are recognized as a powerful means of teaching in other disciplines, but it seems that in philosophy things are different. The clash of paradigms that is emphasized in contemporary literature is mostly often expressed as a clash of student learning 
paradigm versus mere transfer of theory and fact themselves or broadly expressed as a clash of teaching ex cathedra versus dialogue, taking into consideration the history of philosophy, it seems non-existing. Namely, from the very beginnings, philosophy has based its teaching on communication among opposing views. It would be too broad an argument in favor of this when dealing with works of explicitly dialogue type. However, even when dealing with works that do not have an explicit dialogue form, the existence of the other side can be implicitly anticipated, at least fictitiously.

Let's take as an example Spinoza's work Ethics which at least gives space to view it in this way. Namely, as Agnes Van Rees sees in her work, Dissociation in Argumentative Discussions, dissociation as an argumentative technique ${ }^{4}$, can be also recognized in the works of philosophers such as Spinoza. If we follow her train of thought, then, using the dissociation we divide: “... something from something else [...] begin to regard the two things as separate from each other" (Rees 2009, 3). In such a way Spinoza's abovementioned work, led by Perlman's and Olbrechts-Tyteca's work, finds several dissociative couples (e.g. image-idea, universal-individual, passion-action...) (Rees 2009, 19). Furthermore, led by the opinion of these two philosophers, she claims that: "there is no philosophy without dissociation" (Rees 2009, 20), that in our opinion was imposed as a statement according to which nothing in philosophy can be taken as valid without getting to know what is contra to the affirmations.

From the position of the mere historical development of Spinoza's thought, this statement additionally comes to the fore. Although the movement through the work Ethics assumes, as we have already noticed, in some way 'artificial' production of these pairs, his book that precedes the Ethics, Short Treatise on God, Man and His Well-Being, shows these pairs explicitly. We will notice that Spinoza, from the beginning of this work, writes two short dialogues. The first between Understanding, Love, Reason and Desire, and the second one between Erasmus and Theophilus. ${ }^{5}$ It is clear that Ethics develops more geometrico, so that, in principle it counts on, said in Kant's words, the argumentation from the perspective of the synthesis a priori. Still, a strict reliance on pure reason, leaves space to generate proofs from other segments of a human being. From the perspective of these two cited works, it can be projected that Spinoza was aware of a potential dissociation that can be anticipated if we separate the Ethics from the wholeness of his other works. Therefore, in Short Treatise on God, Man and His Well-Being, through the statement Love he tends to: "...turn again to Reason only to proceed and stop the mouths of these foes." (Spinoza 2002, 47), so that, actually, the main role in the cognitive drama he gives to Reason. Not wanting to enter a deeper analysis of Spinoza's entire philosophy, which would be a matter of bad taste and utterly irresponsible, for the sake of our purpose, we can only state the following. It is certain that Spinoza, before writing Ethics had in mind potential dissociative pairs, in this case between Reason and Desire, and that their conflict was solved exactly by a debate. But, it seems that this kind of debate is still closed.

Spinoza's cited works evidently show that without dissociation and rational explanation of the position which is being taken, we cannot truly understand key philosophical stands. However, in a classroom, establishing these two steps is not so simple. More precisely, it does not include only reading a previously prepared text, whether it is a monologue or a dialogue, but also including students' attitudes which are not always reasonable. Reasonability

\footnotetext{
${ }^{4}$ The term 'dissociation' is used in other disciplines such as chemistry or psychology, only with a significantly different meaning.

${ }^{5}$ See in: (Spinoza 2002, 46-50)
} 
should be reached. Namely, we, as philosophy professors, cannot rely on: "(universal) audience that is supposed to guarantee rationality..." (Van Eemeren and Grootendorst 1984, 13), the audience that Spinoza counted on. From this perspective, let us say the previous works are of the closed form, which means they start with an attitude and prove it rationally, but in their framework, they have: "imaginary company of passive listeners offering no verbal opposition..." (Van Eemeren and Grootendorst 1984, 13). Thereby, they, generally, do not cross the lines of conceptual frames which formed them. So, as our explanation of the works suggested, they can be a valid base for searching already existing patterns of discussion and debate, but such a search will not contribute greatly to expanding the perspective, but rather establishing existing ones. As we will explain 'open mindedness' and 'sensitivity to context' in the following paragraph, they are two major characteristics which should be developed through discussion and debate, but by analyzing the work of just one philosopher, be it Spinoza or someone else, as we consider it, is not possible. That is why we will turn to an example from the classroom in order to additionally explain our position on the difference between discussions and debates. This example will take into account both the dialogical and monologic form of the texts being addressed. We believe that one example of a topic in history of philosophy, in addition to pointing out the complexity of the classroom situation, leads us to a classroom conducting structure that will be interpreted more precisely later. It is, as it will be seen, an interpretation of Kant's epistemological position. Hereby, the connecting thread provides insight into: “... a new conceptual basis” (Windelband 1901, 530), which Kant establishes and which can precisely be explained as the insight into establishing more precise dissociative pairs.

\subsection{Classroom Example}

When I go through Kant's Critique of Pure Reason with my students, I am inclined to, aside from the historical position of Kant's work which precedes Schopenhauer's, however, start working with them while bearing in mind Schopenhauer's book The World as Will and Idea. The students are given the task to, while bracketing Schopenhauer's global position, read only the dialogue between the Subject and the Matter, as presented in Schopenhauer's work ${ }^{6}$. In the first place, I intend to do this in order to introduce the concept of 'matter' again, because in Barkley's previously analyzed work Three Dialogues Between Hylas and Philonus, the position of 'matter' is greatly disqualified. What follows, of course, is the development of discussion and after, debate with arguments pro et contra, but what is important at this stage is that the dissociative pair, subject-matter, introduces us with other diversions, important to understand the work of Kant, such as noumenon-phenomenon, $a$ priori - a posteriori, transcendental - transcendent etc.

Therefore, through the first step in conducting class, we again try to establish the fundamental dissociative pair. The pair subject-matter is, as we think, fundamental as long as it represents the connection among three issued concepts. Hence the former example includes concepts, or at least some parts of the concepts of three philosophers, Schopenhauer, Barkley and Kant. It should be mentioned, only formally, that the part from Schopenhauer's book in our perception is an 'open invitation, , not a base for known answered questions.

\footnotetext{
${ }^{6}$ See: (Schopenhauer 1887, 181-183)

${ }^{7}$ Some authors argue for the thesis that the open questions are not sufficient for developing a productive discussion. Hence they say: "various grammatical forms other than questions..." (Willemsen, et al. 2018, 41) which can be equally fruitful for such an initiation.
} 
Speaking of the base for known answered questions ${ }^{8}$, it is connected to Barkley's indicated work and it generally figures in one direction as the base for evaluating acquired knowledge, and in the other as the opposite to Kant's attitudes. We evaluate by asking questions: "What is Barkley's stance on material substance?", "What are Barkley's arguments for the thesis of the non-existence of the pure reason?", "Does Barkley's philosophy include abstract concepts?", and the like. Besides questioning students' acquired knowledge through adequate answers, they suggest a conceptual base which is contrary to Kant's. Kant's conceptual base, as attested by Windelband, included critical overcoming of dogmatism, or epistemological indoctrination, which directed to validity of knowledge only from the position of rationalism, or, only from the position of empiricism: "All philosophy is dogmatic, which seeks to prove or even merely to judge of this validity by showing the genesis of those principles out of elements of sensation, or by their innateness, whatever the metaphysical assumptions in the case may be" (Windelband 1901, 534).

Still, the primary purpose of this class example is not the students' mere acceptance of Windelband's previously presented attitude on Kant's philosophy as an union of rationalism and empiricism, but the acceptance of the fact for the necessity of a struggle between these two concepts. The struggle, of course, happens through discussion and debate. At this moment, if we defined discussion as the exchange of thoughts, then we can hear interesting discussions on the subject, for example on the subject of the 'thing in itself' beyond us. Still, the mere exchange of thoughts does not get us to the ultimate goal we set at the beginning of analyzing these examples, or reaching the 'new conceptual basis'. For that, it is necessary to initiate a debate which would include interpreting both Barkley's and Kant's attitudes. That demands that both positions be well logically formulated, and appropriately methodologically tested.

\section{INFORMAL AND FORMAL STEPS}

In view of the previously explained, it can be ascertained that the difference between discussion and debate has been generally examined through the prism of reasonability. This means that the debate was, in a way, 'burdened' by a logical and methodological form of argumentation, and the discussion as its predecessor had a more loose framework, which does not directly concern the rational structuring of the philosophical problem, but its perception, generalization, and for the purpose, as it has already been remarked, to make 'spotted' dissociative pairs available to the debate. From this perspective, the discussion finds its goal in answering the question that the representatives of 'mundane reasoning' ask in the following way: "How come, he sees it and you do not?" (Habermas 1984, 13). Thus, the primacy of discussion over the debate is reflected in the fact that it opens the field of perception of the existence of the problem and its precise placement before the pro et contra form. After that, the debate remains in the task of determining the strength of the argument through logical and methodological frameworks. As it turns out before that, an informal side of the lesson structuring is necessary.

Specifically applied to our work, and taking into account what was available to us from the proposed concepts, it would have been necessary to overcome a sufficiently broad structure that counts with both informal and formal lesson management. To begin with, let us state some of the most widespread aspects of these structures. In our

\footnotetext{
${ }^{8}$ See: (Willemsen, et al. 2018, 40)
} 
methodical legacy, there is a dominant pattern of conducting the dialogue through three steps: scandalon, problematization, actualization. ${ }^{9}$ From another perspective, according to Mason's testimony, Enis offers the following steps: "observing, inferring, generalizing, reasoning, evaluating reasoning ...” (Mason 2008, 2). Next, Dewey suggests the following steps: "Become aware of the problem, define it, propose various hypotheses to solve it, examine the consequences of each hypothesis in the light of previous, experience and test the most likely solution." (Paris n.d.). The custom conceptual framework of lesson management in philosophy Kienstra and her associates see through the implementation of the following steps: "rationalizing, analyzing, testing, producing criticism, and reflecting" (Kienstra, et al. 2015, 1).

As it can be seen from the previous, much more attention is paid to formal forms of dialogue with students, which include: inferring, rationalizing, problematization, actualization, analyzing, testing, examine the consequences of each hypothesis in the light of previous. Yet are, although not at all (in example, not in Kienstra's work), are taken into account and those informal forms which are stated completely: observing, scandalon, become aware of the problem. We also add to this listing a step of 'work on negation' as seen from the perspective of the UNESCO book Philosophy a School of Freedom. In our way, as we know it, the lesson structure should start with the combination of these informal steps. Other forms related to strictly formal structuring take the classical form of the derivation of the premise, their structuring into logical and methodological patterns, and the conclusion derivation eventually. An important segment of these formal steps is the identification of logical errors of which forms we should be informed. Although, formal and these steps can be structured differently depending on the logical preferences of the teachers themselves. Namely, this difference stems from whether the strength of argumentation will be based on a dialectical, strictly logical or rhetorical approach, which is, of course, determined by the content of the problems being addressed. However, whatever approach you choose, there is already a predefined form that needs to be debated. To recap, the matter with problem identification, comprehension of the covert or open dissociation, understanding its significance and interest in the debate implies the development of a character disposition, and not so much the structuring of the already expressed opinion into predefined forms. Therefore, the goal of informal steps of teaching philosophy is to awaken what philosophical methodologists call 'open-mindedness'.

It is certain that informal steps have yet to create something, 'become aware of the problem' and some sort of, even a rudimentary opinion on the problem. And, no matter how contradictory it sounds, this should awaken students' 'immaturity'. Also, with this, we have in mind John Dewey's book Democracy and Education. In this book, we come across a very interesting chapter in which he affirmatively and positively speaks about immaturity. From that perspective, immaturity was seen as a key condition for development in education. The setting is briefly reduced to the following: if we think we are mature in a certain domain, we do not see the need for further education and progression in it. By following Dewey's trace and trying to avoid this state, we are working on the awakening of plasticity as: "... the power to retain from one experience something which is of avail in coping with the difficulties of a later situation." (Dewey, 2001, p. 49). And although Dewey describes this plasticity as something: "... different from the plasticity of putty or wax" (Dewey 2001, 49), and in a way deviates from the interpretation of this problem in the way

${ }^{9}$ See: (Marinkovic 1983, 29-39) 
that we are going to present it, we still deem that a view such as this can prove helpful in clarifying our position. Therefore, let us start from the historic roots of this concept and try to explain how it is applied in a contemporary context.

Namely, Plato, in his well-known dialogue Theaetetus that mostly tackles the problems of knowledge, offers one very inspiring metaphor for our contemporary problem [Theaet. 191c]: "Please assume, then, for the sake of argument, that there is in our souls a block of wax, in one case larger, in another smaller, in one case the wax is purer, in another more impure and harder, in some cases softer, and in some of proper quality" (Plato, 185). With this in mind, Burnyeat expresses his 'Wax Block model' view. He opines that from this metaphor can be discerned: "... how the capacity for learning and retention varies from one person to another according to the qualities of their wax" (Burnyeat 1990, 92). Reflecting, from this position, on Dewey's previously interpreted concept of immaturity and plasticity, we can say that only on a platform of higher plasticity can a certain quality for knowledge be developed. Burnyeat further specifies that: “...for this purpose the Wax Block model is a highly effective means to make us separate, in imagination, the new perception from the 'signature' applied to it" (Burnyeat 1990, 92). Therefore, we have a task to, metaphorically speaking, change the state of matter of the awareness of our students.

A good starting position in this attempt can rely on the growth of the informative content that is related to the problem at hand. Popper suggests that this can be done with a specific method of developing conjunction. He is specific, inasmuch as he does not count on increasing the conjuncts within a given problem or concept, but counts on the increase, or more specifically, growth of the situations in which some of the problems can be considered. And although this increases the informative content of a proposition, seen through the prism of the 'calculus of probability', its cognitive potential decreases. That, by mirroring Popper, can be presented like this - regarding the informative content, bringing new contexts where the problem can be found into the game, leads to the following formula. If ' $\mathrm{A}$ ' is the first context, ' $\mathrm{B}$ ' the second, wider context, ' $\mathrm{C}$ ' the third and the widest, we have the following situation: $\mathrm{A}<\mathrm{B}<\mathrm{C}$. On the other hand, the situation regarding the probability of cognition related to the context $\mathrm{A}$, or more specifically, its relevance for the other wider contexts, is less likely, so regarding the certainty of cognition, we have $\mathrm{A}>\mathrm{B}>\mathrm{C} .{ }^{10}$ As Popper notices, there is something paradoxical here, which can be understood as a remark that the purpose of education is increasing the probability of somebody's knowledge, and that with this step, we are suggesting something else. In the widespread understanding of knowledge: "these two aims are incompatible" (Popper 1995, 218). Therefore, the numerous suggestions to Popper actually had the aim of setting aside this line of thinking and turning to the analysis of cognition based on the 'calculus of content' and the 'calculus of relative content'. Here, we will not delve deeper into defending the cause of setting the given pattern the way Popper did. We cannot say that his defense is not convincing, but here, we still do not function in the domain of logic, so every invocation of it here is superfluous.

Also, 'work on negation' can be used for the same purpose as the previous: "First, there is work on negativity recommended by Hegel as an integral part of the dialectic process, and a necessary condition for access to reality or anything deserving the name of ' thought '." (UNESCO 2007, 176). In fact, it is only by acquitting ourselves, by denying the fundamentals, or, in a somewhat milder form, by the suspicion of the foundations of our opinions, by distance in relation to them, we can perceive the problems and affirm a

\footnotetext{
${ }^{10}$ For more specific meaning and representation of these formulae, see: (Popper 1995, 218)
} 
wider image of the world. It is certain that such a disposition cannot be developed through the application of a rational form. It is rather a matter of talent, pedagogic eros, as earlier noted, to provoke the question of the content itself, to place a 'trap' to an established opinion of how Marinković depicts. Hence, it counts on constant innovation, rather than on already established forms.

\section{CONCLUSION}

Finally, and if we were to put together some kind of structured outcome from the conglomerate of the given steps to conduct discussions and debates, then the only thing we can say is that a well-organized philosophy lesson guided by the way of discussion and debate must take into account equally informal and formal steps. Certainly, the primary place belongs to informal steps, and only then to the formal ones. The rest is relative. In some form, the concept could look like this: 1 . observing, 2. scandal on-negation, 3. generalizing-definingrationalization, 4. producing criticism, 5. reasoning-analysis, 6. testing-inferring, 7. reflecting, but that is not a final concept. Some of the steps can be skipped depending on the material being processed, or from the achieved level of philosophical education of the students, etc. However, some of them may be re-implemented or the whole structure re-implemented within step 7. Therefore, the proposed concept can also be viewed through an image of concentric circles. Due to the overlap in the determination of these steps, the positions of some of them may be replaced. Nevertheless, it remains to be concluded that when it comes to a discussion, informal steps have the primacy while formal ones go with the debate.

\section{REFERENCES}

Bhatt, B. Modern Methods of Teaching. Darya Ganj, New Delhi: Kanishka Publishers, Distributors, 1995. Burnyeat, M. The Theaetetus of Plato. Indianapolis/Cambridge: Hackett Publishing Company, 1990.

Classroom Discussions. (n.d.). Retrieved January 18, 2018, from Teaching and Learning Transformation Center University of Maryland: https://tltc.umd.edu/classroom-discussions

Dewey, J. Democracy and Education. Pennsylvania: Pennsylvania State University, 2001.

Habermas, J. The Theory of Communicative Action, Reason and The Rationalization of Society. Boston: Beacon Press, 1984.

Kienstra, N., J. Imants, M. Karskens, \& P. G. van der Heijden. "Doing Philosophy Effectively: Student Learning in Classroom Teaching". PLoS ONE 10, 9 (2015): 1-23.

Longman Dictionary of Contemporary English. (n.d.). Retrieved December 25, 2016, from https://www.ldoceonline. $\mathrm{com} /$

Macmillan Dictionary. (n.d.). Retrieved December 25, 2016, from https://www.macmillandictionary.com/ british-and-american-pronunciation.html

Marinkovic, J. Metodika nastave filozofije. Zagreb: Školska knjiga Zagreb, 1983.

Mason, M. "Critical Thinking and Learning". In Critical Thinking and Learning, edited by M. Mason, 1-11. Oxford: Blackwell Publishing, 2008.

Paris, N. A. (n.d.). Major educational philosophies. Retrieved September 15, 2018, from http://ksuweb.kennesaw. edu/ nparis/educ7700/EDUCATIONAL\%20PHILOSOPHIES\%20(Major).doc

Plato. Theaetetus, Sophist. London: William Heinemann, 1921.

Popper, K. Conjectures and Refutations. London: Routledge, 1995.

Rees, A. V. Dissociation in Argumentative Discussions. New York: Springer, 2009.

Schopenhauer, A. The World as Will and Idea. Boston: Ticknor and Company, 1887.

Spinoza, B. "Short Treatise on God, Man, and His Well-Being”. In Spinoza, Completed Works, edited by M. L. Morgan, 46-50. Indianapolis/Cambridge: Hackett Publishing Company, Inc., 2002.

UNESCO. Philosophy. A School of Freedom. Paris: UNESCO Publishing, 2007. 
Van Eemeren, F. H., \& R. Grootendorst. Speech Acts in Argumentative Discussions. Dordrecht, Cinnaminsom: Foris Publication, 1984.

Van Emeren, F. H., B. Garssen, E. C. Krabbe, A. F. Henkemans, B. Verheij \& J. H. Wagemans. Handbook of Argumentation Theory. New York, London: Springer Reference, 2014.

Wallwork, A. Discussions A-Z Advanced. A Resource Book of Speaking Activities. Cambridge: Cambridge University Press, 1997.

Willemsen, A., M. N. Gosen, M. van Braak, T. Koole, \& K. de Glopper. "Teachers Open Invitations in Wholeclass Discussions". Linguistics and Education 45 (2018): 40-49.

Windelband, W. A History of Philosophy. New York: The Macmillan Company, 1901.

Јањић, М., Ј. Максимовић, Г. Ђигић и С. Божић. Практикум за реализацију професионалне наставне праксе. Ниш: Филозофски факултет, 2014

\section{NEFORMALNI I FORMALNI KORACI U VOĐENJU DISKUSIJA I DEBATA KAO NAČINA POUČAVANJA FILOZOFIJI}

Namera autora ovog rada je da odredi jednu precizniju strukturu za vođenje diskusija i debata kao najboljih načina kroz koje valja poučavati filozofsko gradivo. U prvom delu rad će se iscrpsti u pokušaju da se između diskusija i debata uspostavi preciznija razlika, kako bi platforma zbog koje se razvijaju neformalni i formalni koraci u vođenju istih bila jasnija. Pri tome ce se pokazati kako se iniciranje diskusije i njeno vođenje uglavnom bazira na neformalnim koracima, a vođenje debate na formalnim. Kroz jedan kraći ekskurs, autor će pokušati da obrazloži i pojam 'disocijacija' kao duboko fundiran u bilo kom pristupu filozofskoj problematici, bez obzira da li je on koncipiran mološki ili dijaloški. U tu svrhu biće iznešen i jedan primer iz same učionice. Sa takve pozicije autor će u završnom delu rada iz konglomerata koraka koji se preporučuju za uspešno vođenje časa izvući one koji se najbolje uklapaju u ovako viđen koncept određenja i vođenja diskusija i debata.

Ključne reči: diskusija, debata, disocijacija, neformalni koraci, formalni koraci. 